\title{
INTRA-CELLULAR LIPIDS OF CARTILAGE
}

BY

\author{
The late D. H. COLlinS, F. N. GHADIALLY, AND G. MEACHIM \\ Department of Pathology, University of Sheffield
}

It has been known for some time that the chondrocytes of various cartilages normally and regularly contain lipid droplets in their cytoplasm. Sheehan (1948) regarded cartilage cells as "having an inherent capacity to store lipid in large quantities". Montagna (1949), arguing from the histochemical reactions, considered the larger lipid droplets to be neutral fats and the smaller droplets to contain fatty acids and in some cases phospholipids.

Fawcett (1954) stated that "mature chondrocytes commonly have in their cytoplasm several large droplets of lipid" and that since a considerable amount of lipid was present in healthy growing cartilage (Clark and Clark, 1942) its presence should not be considered as evidence of degeneration or of poor nutrition, but rather of the capacity of chondrocytes "to store and synthesize neutral fat". This view was also supported by Carlson (1957). Ham and Leeson (1961) merely stated that "glycogen and fat may be demonstrated in the cytoplasm of large chondrocytes". Barnett, Davies, and MacConaill (1961) stated that "lipids are present in all chondrocytes", and that their presence was not related either to age or degeneration. They illustrated lipid droplets in the articular cartilage cells of a young rat. They postulated that, since chondrocytes could be shown to contain much lipase in the cytoplasm (Montagna, 1949), the lipids might accumulate there prior to their conversion to carbohydrates, a view in direct opposition to that of Montagna (1949) that the lipids might have been converted from carbohydrates since glycogen seemed to be stored before lipids appeared.

Davies, Barnett, Cochrane, and Palfrey (1962) recorded the electron microscope appearance of cytoplasmic fat globules in the lower middle zone of rabbit articular cartilage and of occasional small fat droplets in the cells of the upper middle zone. It seemed likely that the fat was enclosed between pairs of cytomembranes. Later reports of electron microscope studies of articular cartilage of rabbits (Barnett, Cochrane, and Palfrey, 1963) and of mice (Silberberg, Silberberg, and Feir, 1964) made no particular observation on the intra-cytoplasmic lipid globules, though Barnett and others (1963) refered to and illustrated whorled myelin bodies in degenerating surface cartilage.

For some time we have been studying the lipids of various cartilages both with frozen sections and fat stains and with the electron microscope. It is quite clear that hyaline cartilage may contain lipids in two sites, within the cytoplasm of the chondrocytes and in the matrix outside the cells. This first paper describes our study of intra-cellular lipids.

\section{Material}

\section{LIGHT Microscopy}

Tissue for examination by light microscopy was obtained as follows:

Rabbit Costal and Bronchial Cartilage: Sections were examined from six rabbits aged $2 \mathrm{mths}$ (approximately $800 \mathrm{~g}$.) and from twelve adult rabbits $(2-3 \mathrm{~kg}$.). The specimens were taken from a lower costal cartilage anteriorly and from a main bronchus.

Hamster Costal and Bronchial Cartilage: Sections of costal and of bronchial cartilage were examined from two hamsters aged 2 days, from two aged 6 months, and from two aged 2 years. All the animals were golden strain Syrian hamsters of one colony, bred and maintained at the University cf Sheffield Field Laboratories.

Human Costal Cartilage: Samples of human costal cartilage were taken at necropsy from subjects whose ages ranged from premature birth to 74 years.

Rabbit Articular Cartilage: Specimens of articular cartilage from the head of the humerus were examined from 2-mth-old rabbits (approximately $800 \mathrm{~g}$.) and from adult rabbits $(2-3 \mathrm{~kg}$.).

Human Articular Cartilage: Eight specimens of juvenile articular cartilage were taken at necropsy from the head 
of the humerus. The subjects comprised premature neonates, full-term babies, and two 8-year-old children. Adult specimens of articular cartilage were taken at necropsy or at operation from the central part of the head of the humerus, from near the edge of a femoral condyle, and from the patellar groove of the femur. The age of the subjects ranged from 28 to 83 years. In most instances the specimen was collected by cutting out a block of cartilage from above the level of the calcified zone, thus avoiding the need for subsequent decalcification.

\section{Electron Microscopy}

Tissue for examination by electron microscopy was obtained as follows:

Costal Cartilage: Costal Cartilage was taken from an adult rat.

Articular Cartilage: Rabbit articular cartilage was taken from the patellar groove of the femur in adult animals $(2-3 \mathrm{~kg}$.). Human articular cartilage was obtained at operation prior to mid-thigh amputation in a man aged 58 and in a woman aged 83 years. A superficial strip of articular cartilage was removed from near the edge of a femoral condyle.

\section{Methods \\ I. Light Microscopy}

The specimens were fixed in femoral-calcium; frozen sections were cut, stained with oil red $O$ and Harris' haematoxylin, and mounted in glycerine jelly. Decalcification, where needed, was carried out in ethylenediamine-tetra-acetic acid (E.D.T.A.) at room temperature.

The size of intra-cytoplasmic lipid drops as seen on light microscopy of the oil red $O$ preparations was recorded as follows:

"Fine drops"- Only just visible when using the $\frac{1}{6}$ objective.

"Small drops"- Readily seen with the $\frac{1}{6}$ objective, of sizes up to half that of the nucleus.

"Large drops"- Sizes over half that of the nucleus. In some cartilages drops considerably bigger than the whole of the nucleus were encountered.

\section{EleCtron Microscopy}

Small pieces of cartilage were fixed in osmium according to the method of Palade (1952). The tissues were then processed and embedded in Araldite (Glauert, 1961) and sectioned with either the Huxley or the Porter-Blum microtome. Sections were mounted on uncoated copper grids, stained with lead citrate or uranyl acetate, and examined with the A.E.I. EM6 using an accelerating voltage of 50 or $75 \mathrm{Kv}$.

\section{Results \\ I. Light Microscopy \\ Rabbit Costal and Bronchial Cartilage}

The bulk of both the costal and the bronchial cartilage is formed by rounded chondrocytes embedded in intercellular matrix. At the periphery of costal cartilage and of bronchial cartilage plates there is a narrow rim of slender, elongated subperichondrial cells.

The appearance in oil red $O$ preparations is similar in costal and in bronchial cartilage, but the pattern in the 2-mth-old rabbits examined differs from that seen in the adult animals.

2-mth-old Rabbits.-In the oil red O preparations no lipid is demonstrated in the outermost rows of subperichondrial cells, but lipid is apparent in most of the elongated cells in the deeper layers of subperichondrium. It is seen as one or in an occasional cell as two small drops, often lying close to one end of the elongated nucleus. At the junction of the zone of flattended subperichondrial cells with the area of rounded chondrocytes multiple fine drops are seen in some of the cells.

The rounded cells which occupy the bulk of the cartilage each usually show multiple drops of lipid. Often one, or occasionally two, of the lipid drops are large, and thus more prominent than the rest (Fig. 1). However, in the 2-mth-old rabbits examined, these large lipid drops do not reach the size seen in the central area of costal and bronchial cartilage from adult rabbits. Their size never greatly exceeds that of the nucleus, and the nucleus itself is rounded and not displaced to the periphery of the cell.

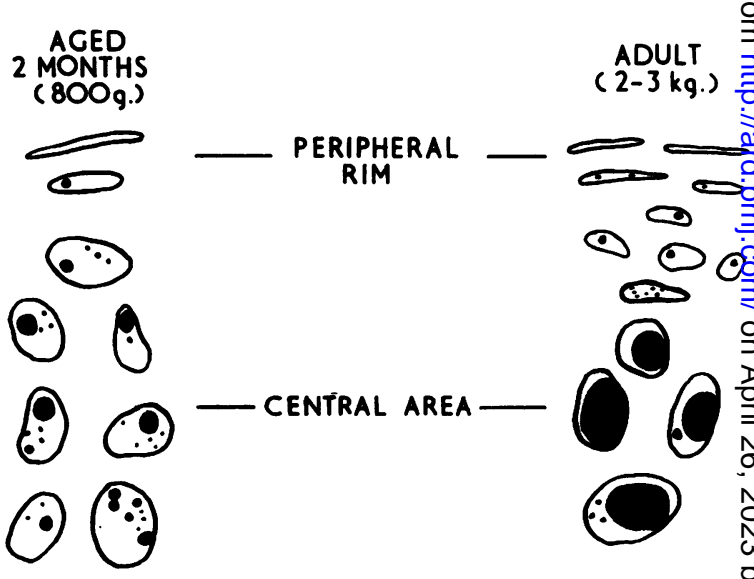

Fig. 1.-Semi-diagrammatic representation of intra-cellular lipid in rabbit bronchial cartilage. Aged 2 months $(800 \mathrm{~g}$.) on the left; adults (2-3 kg.) on the right. The nuclei are not shown. Drawn from oil red $\mathrm{O}$ preparations.

Adult Rabbits. - In the subperichondrium and in the rounded cells close to it the appearance in oil 
red $\mathrm{O}$ preparations is similar to that seen in the younger animals.

Towards the centre the rounded chondrocytes forming the bulk of the cartilage are mainly large, and nearly all show a large lipid drop. Some also show a variable number of small and fine drops; and in an occasional cell only these are present. The size of the large lipid drop often considerably exceeds that of the nucleus, and in some of the cells the nucleus is displaced to the periphery and shows an oval rather than a rounded shape. The appearance thus differs from that in the 2-mth-old animals (Fig. 1).

\section{Hamster Costal and Bronchial Cartilage}

The intra-cellular lipid pattern in oil red $\mathrm{O}$ preparations is fairly similar in costal and in bronchial hamster cartilage, but differs at both these sites according to age.

In the 2-day-old hamsters, intra-cellular lipid is inconspicuous in both costal and bronchial cartilage (Fig. 2). It is just visible in the oil red O preparations in the form of one to four fine drops in about every other cell.

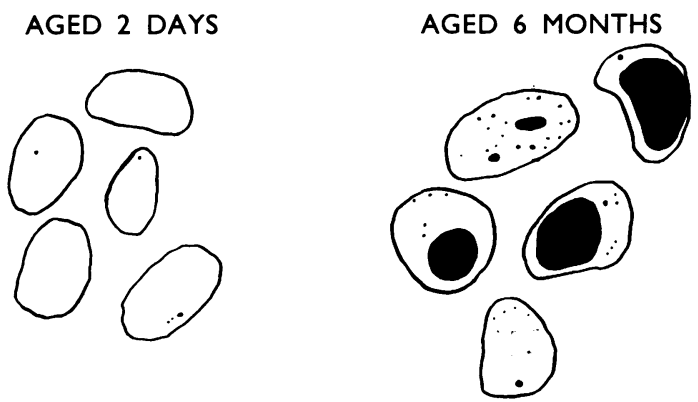

Fig. 2.-Semi-diagrammatic representation of intra-cellular lipid in cells which occupy central bulk of hamster costal cartilage. Aged 2 days on the left; aged 6 months on the right. The nuclei are not shown. Drawn from oil red O preparations.

Intra-cellular lipid is much more conspicuous in costal and bronchial cartilage from the 6-month and 2 -year-old hamsters, and is present in nearly all the cells which occupy the central part of the cartilage (Fig. 2). The majority of these cells in the bronchial cartilages, and approximately half of the cells in the costal cartilages, show a large lipid drop, bigger than the nucleus, together with one or more smaller drops (Fig. 2). The rest of the cells contain two or more drops, but no drop exceeding the nucleus in size. No notable differences could be detected between the hamsters aged 6 months and those aged 2 years.

\section{Human Costal Cartilage}

In the slender, elongated chondrocytes which lie in the peripheral rim of the costal cartilage just below the perichondrium, the intra-cellular lipid pattern is similar at all ages. In all cases the majority of the cells in this subperichondrial region each show from one to three small drops, although in some of the oil red $O$ preparations no lipid is demonstrated in the outermost rows of chondrocytes.

The central mass of the cartilage contains plumper cells, elongated, oval, or rounded in shape. In man, the intra-cellular lipid pattern of these cells shows some variation with age, though less striking than in the rabbit and the hamster.

In premature babies dying shortly after birth, in full-term babies, and in infants up to the age of 13 months, nearly all of the central chondrocytes contain lipid drops in varying size and number. Often one or two of the drops present in a cell are larger and thus more prominent than the rest, but drops much exceeding the nucleus in size are rarely seen (Fig. 3).

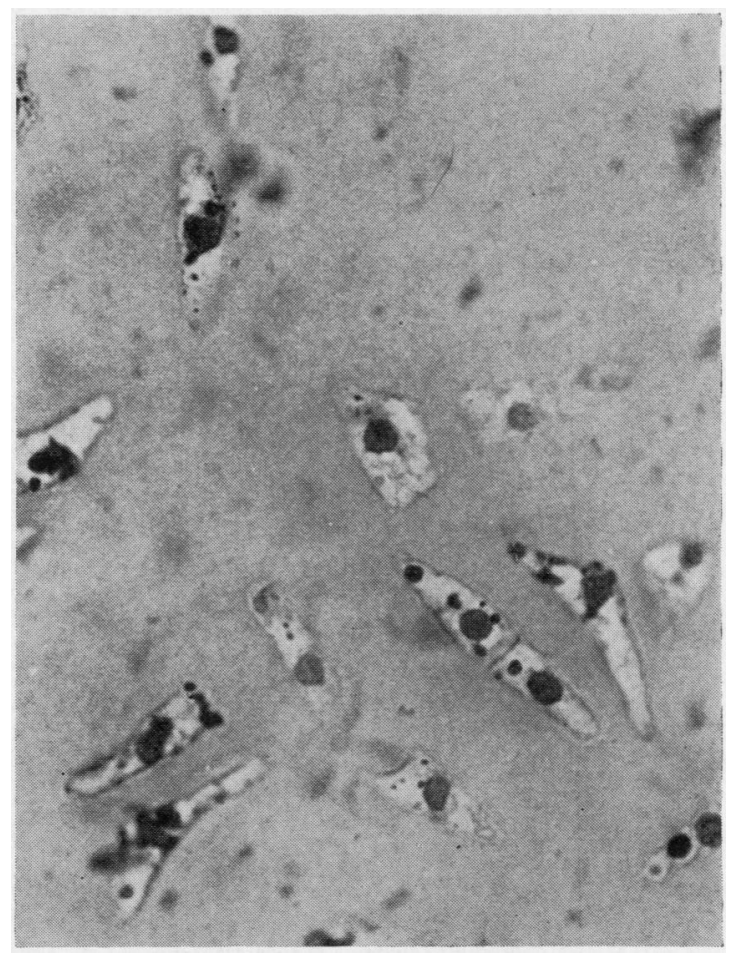

Fig. 3.- Intra-cellular lipid in central cells of human costal cartilage. Necropsy specimen from infant aged 13 months. Oil red $O . \times 500$.

Above the age of 8 years, most of the central cells each contain multiple drops of lipid. In some of the specimens a proportion of the central cells show a large drop which is much bigger than the nucleus 
and which is seen in company with small and fine drops (Fig. 4). Cells with a major drop of this size are in general a good deal less numerous than in the adult rabbit and in the adult hamster costal cartilage.

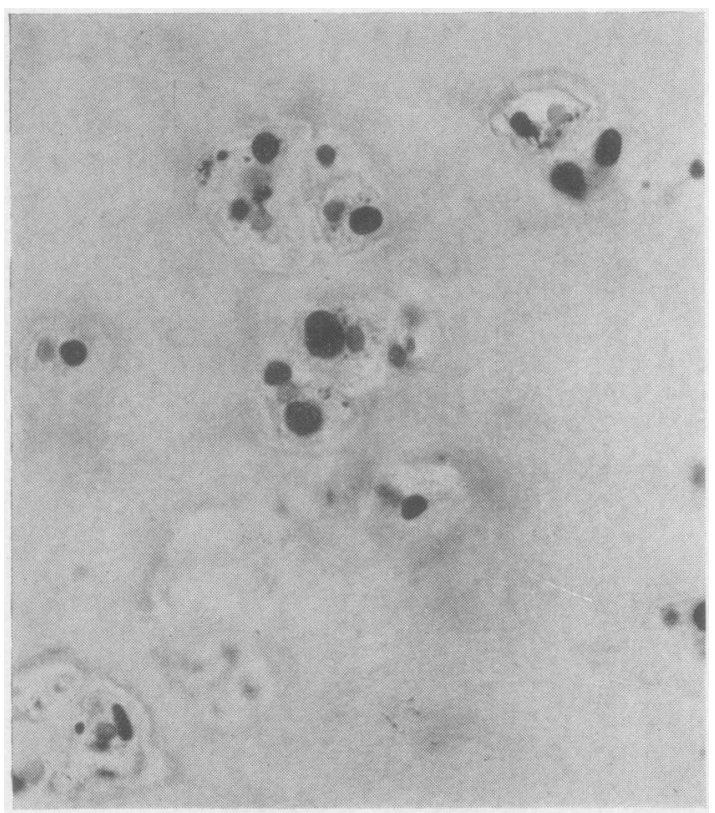

Fig. 4.-Intra-cellular lipid in central cells of human costal cartilage. Necropsy specimen from boy aged 10 years. Oil red $O . \times 500$.

\section{Rabbit Articular Cartilage}

2-mth-old Rabbits. - In the most superficial region of the articular cartilage hardly any of the chondrocytes show intra-cellular lipid; an occasional cell is sometimes seen with one or two small drops. In the rest of the cartilage lipid is more obvious, and from a quarter to over a half of the cells show one, two, or sometimes more, small drops.

Adult Rabbits.-The overall amount of intracellular lipid in the oil red $O$ preparations appears to be greater than in the 2-mth-old animals, but is again seen only as small drops.

In several specimens the most superficial chondrocytes contain no lipid. In others many of the cells in the superficial layer contain a variable number of small drops.

Below the superficial layer the rest of the uncalcified part of the cartilage has lipid in a majority of its cells in all the specimens examined, mostly in the form of one or a few small drops, though, in some of the specimens, cells with numerous fine drops are frequent. In the calcified zone a variable proportion of the chondrocytes contain lipid.

\section{Human Articular Cartilage}

Juvenile (0-8 years). - The sections show no clear boundary between the permanent articular cartilage and the underlying temporary cartilage of the epiphysis, but for descriptive purposes two regions can be recognized:

(a) The region adjacent to the articular surface containing fairly closely spaced oval and rounded chondrocytes;

(b) The deeper region containing more widely spaced oval cells with which are mixed a large number of greatly elongated cells.

None shows osteo-arthritic fibrillation.

In the premature neonates and in the babies, the overall amount of intra-cellular lipid in region $(a)$ is less than that seen in articular cartilage from adults, but in the two 8-year-old children the intra-cellular lipid in this region is similar in amount and in size of drops to that seen in many adults.

Adult (28 to 83 yrs).--Some of the adult cartilages were free from osteo-arthritis while others showed superficial or deep fibrillation.

In both fibrillated and non-fibrillated cartilages, sections stained with oil red $\mathbf{O}$ show intra-cellular lipid in most of the chondrocytes at all levels below the surface. The lipid is seen only as small drops.

In the zone of radially aligned chondrocyte columns the majority of the cells show from one to four or occasionally more small lipid drops (Fig. 5); in a few of the preparations cells showing more than four lipid drops form the majority in the sample.
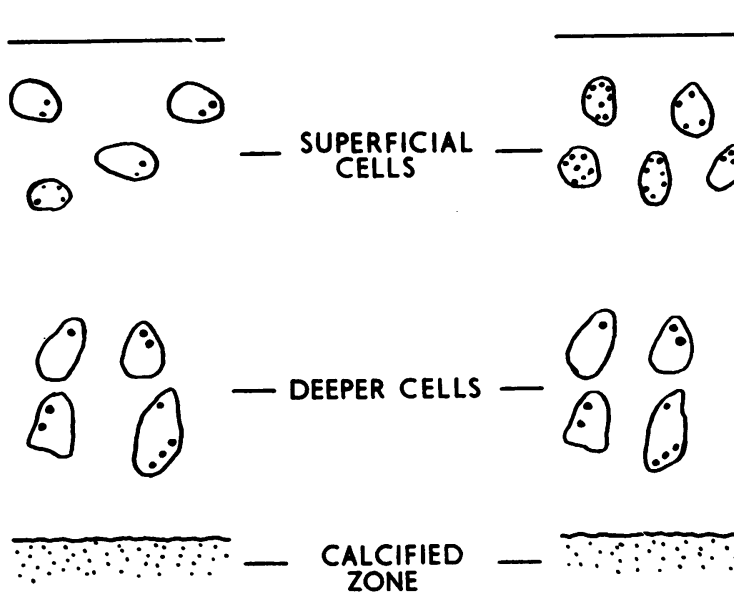

Fig. 5.-Semi-diagrammatic representation of intra-cellular lipid in adult human articular cartilage. Specimens in which the intracellular lipid pattern is similar in both the superficial and the deeper cells are represented on the left; specimens in which cells with many drops are more numerous in the superficial zone are represented on the right. The nuclei are not shown. Drawn from oil red $O$ preparations. 
In about half of the specimens, the cells of the superficial and transitional zones show a similar pattern of intra-cellular lipid to that seen in the deeper zones. In the other specimens cells containing many small and fine drops are more numerous in the superficial zone (Fig. 5). The supərficial zone sometimes also shows aggregates of small and fine drops of lipid, occupying an area resembling that of a cell but without any demonstrable nucleus.

Multicellular chondrocyte clusters are seen in some of the fibrillated areas of cartilage. It is known from previous work that these clusters are often actively engaged in sulphating ground substance (Collins and McElligott, 1960). Their intracellular lipid content is thus of interest. In fact it is so variable in amount that it is hard to say whether there is more or less fat in these cells than in the chondrocytes of non-osteo-arthritic cartilage.

When the calcified zone was included in the preparation, it was apparent that many of its chondrocytes contained small drops of lipid.

\section{Electron Microscopy}

\section{Rat Costal Cartilage}

In the electron micrographs (Figs 6 to 8), differing patterns of intra-cellular lipid are seen. All these patterns have been noted in chondrocytes showing no evidence of degenerative changes.

Some of the subperichondrial oblong chondrocytes show only one or two small lipid drops (Fig. 6), while other oblong cells, probably more deeply situated, contain several drops, some of which may approach the nucleus in size (Fig. 7, see p. 128). The more rounded cells which occupy the central

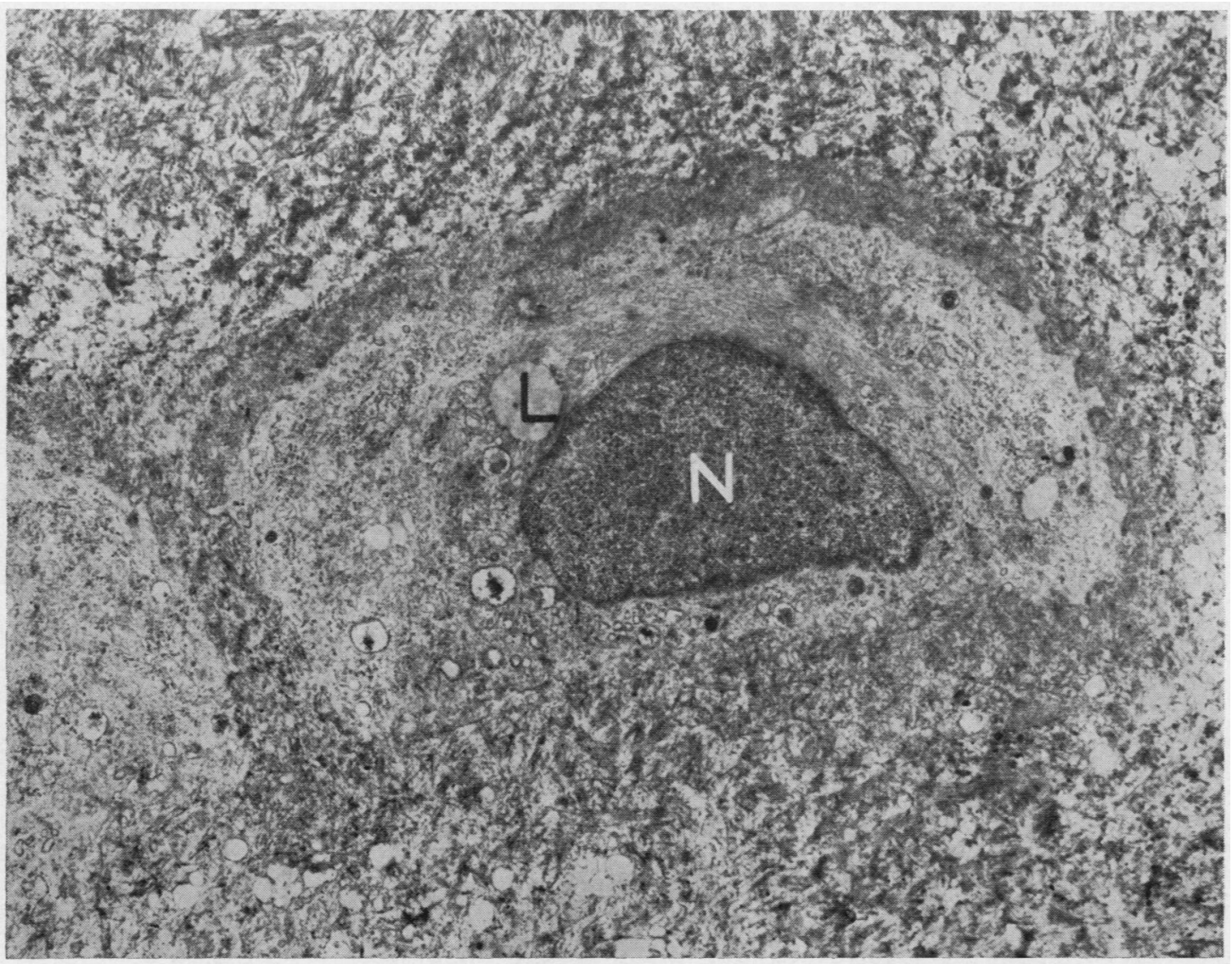

Fig. 6.-Electron micrograph of adult rat costal cartilage, showing oblong chondrocyte containing a small lipid drop (L) near the nucleus $(\mathrm{N})$. Uranyl acetate. $\times 6,000$. 


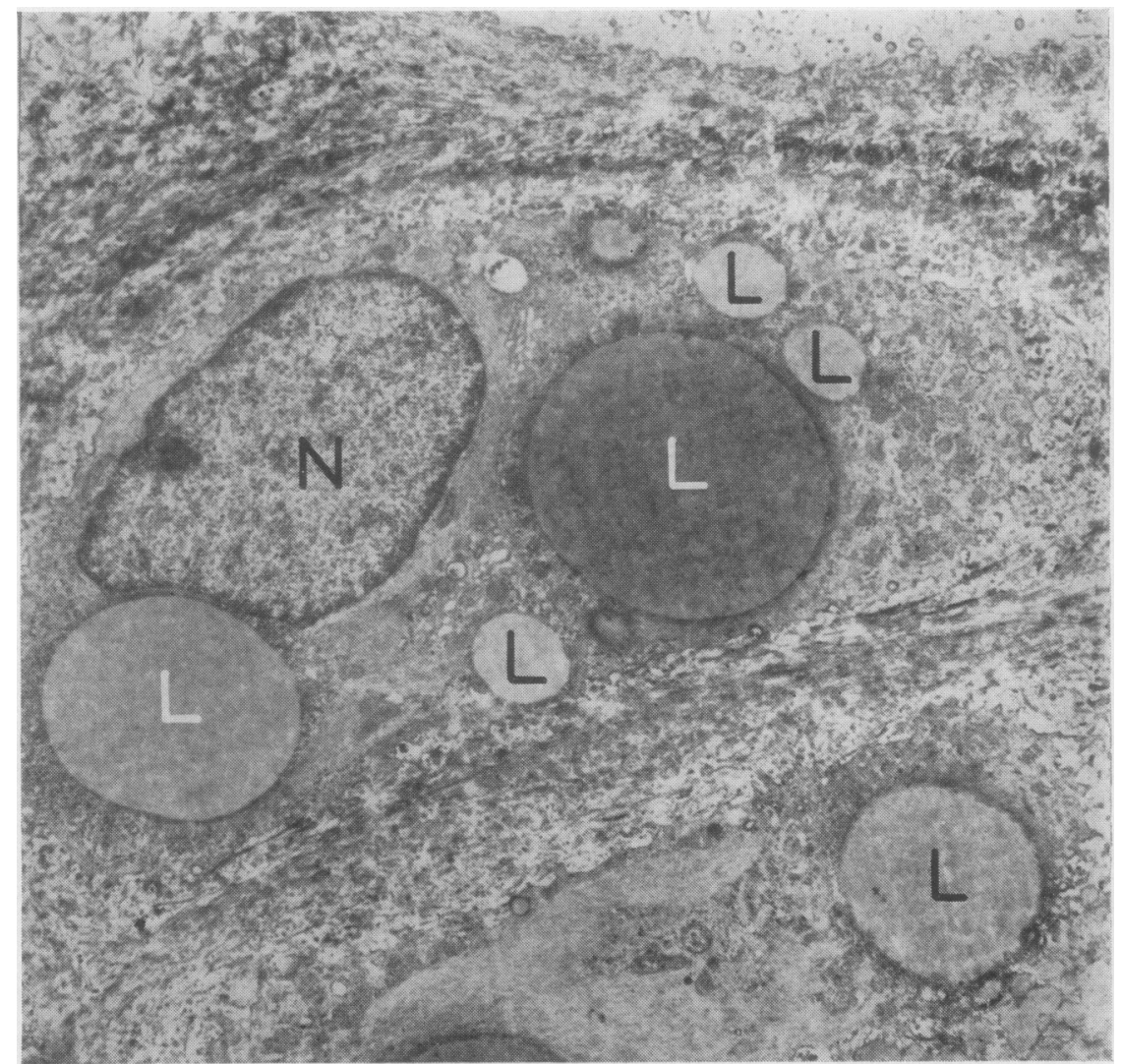

Fig. 7. - Electron micrograph of adult rat costal cartilage, showing oblong chondrocyte with several lipid drops (L), two of which approach the nucleus $(\mathrm{N})$ in size. Uranyl acetate. $\times 6,000$.

mass of the cartilage mostly show one very large globule of lipid, bigger than the nucleus and often displacing or indenting it, as well as one or more smaller drops (Fig. 8, see p. 129).

\section{Rabbit and Human Articular Cartilage}

In both the rabbit and the human material many of the articular chondrocytes show one or more lipid drops (Figs 9 to 12, overleaf). The drops are always smaller than the nucleus. They are rounded but irregular in outline, and their content varies in electron density from medium grey (Fig. 9, see p. 130) to black (Fig. 12, see p. 133). No enclosing membrane has been detected. In general lipid is clearly distinguishable, but sometimes difficulty is experienced in identifying as lipid small rounded structures in the cytoplasm.

An irregular rim of electron-dense granules frequently surrounds the lipid drop, as Chase (1959) described in adipose tissue, and granules are also seen scattered within the drop (Figs 10 and 11, see pp. 131, 132). The granules lack the uniformity of size characteristic of ribosomes, and in the absence of cytochemical data their nature is uncertain.

A relationship of the lipid drop to mitochondria is at times discernible (Fig. 10) and has been recorded by Rhodin (1963) in the liver and by other observers, but this is not a constant feature.

The lipid-containing chondrocytes show an intact nucleus, normal mitochondria with well-orientated cristae, a clearly-defined endoplasmic reticulum with Palade granules, and the absence of degenerative changes.

\section{Discussion}

The observations here reported indicate that normal chondrocytes frequently contain lipid drops. Light microscopy has demonstrated intra-cellular lipid in various hyaline cartilages at various ages in several different mammalian species; the lipid is seen in forms ranging from a single small or fine drop to many of these or to a large drop which can be much bigger than the nucleus. Electron microscopy 


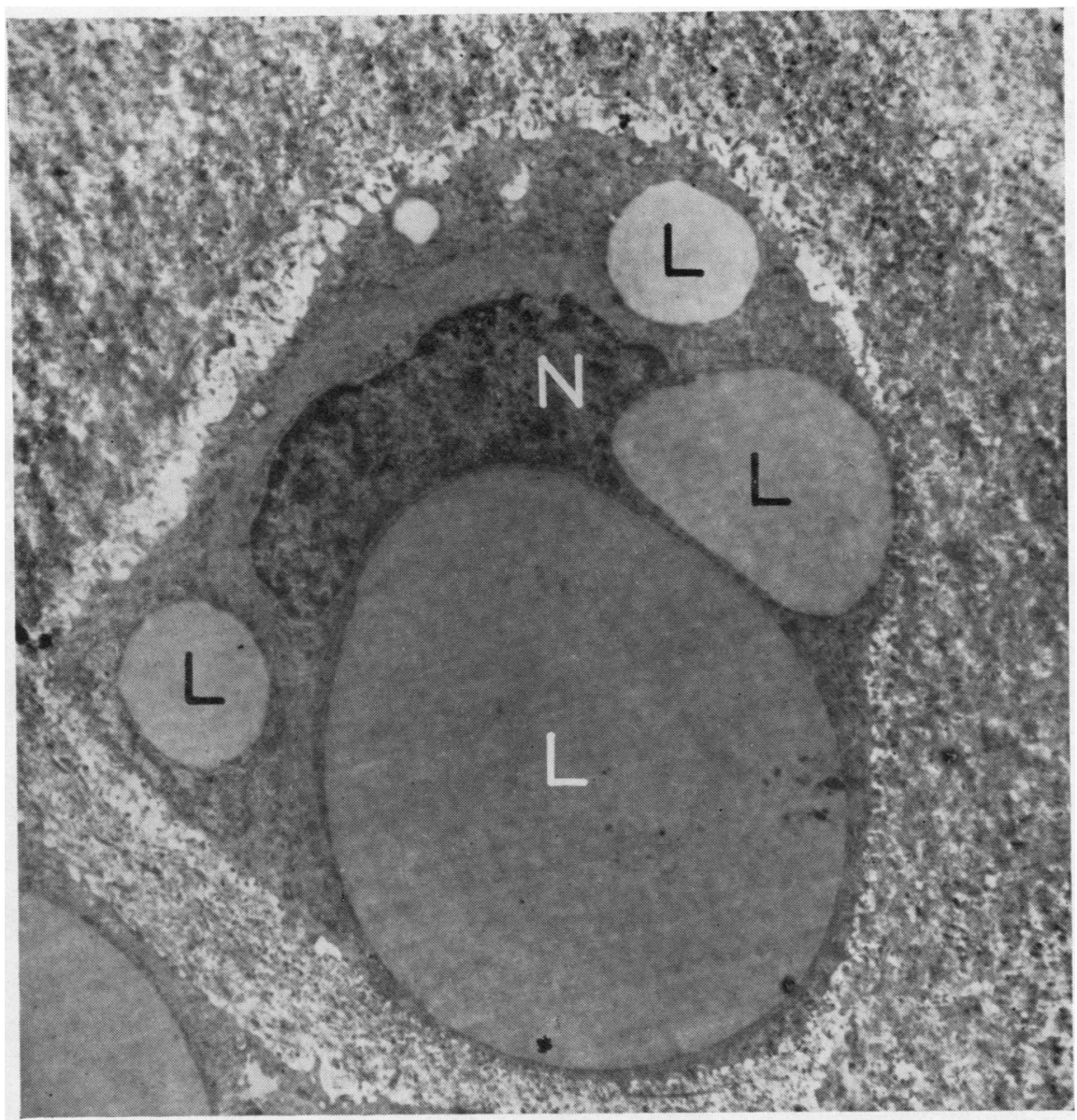

Fig. 8.-Electron micrograph of adult rat costal cartilage showing chondrocyte with bulky globule of lipid (L) and several smaller lipid drops (L). Note that the major globule is much bigger than the nucleus $(\mathrm{N})$, and note also the displacement of the nucleus towards the periphery of the cell. Uranyl acetate. $\times 6,000$.

shows a corresponding range of intra-cellular lipid patterns, and indicates that each of these can occur in apparently healthy chondrocytes. Thus the presence of lipid drops in a chondrocyte is not evidence of degenerative change, a conclusion in line with that of Fawcett (1954) and that of Barnett and others (1961).

The biological significance of lipid storage in healthy chondrocytes is unknown. Possibly it is an adaptive phenomenon related to the topography of hyaline cartilage. Nutrients from blood or synovial fluid can reach the cartilage cells only by movement through the intercellular ground substance. However, many chondrocytes do not lie close to blood vessels or to the articular surface. Their intracytoplasmic lipid drops may therefore function as a readily accessible store of material which can be used as a source of energy or chemical building blocks for metabolic activities in the cell.

A second possible function of the intra-cellular lipid is suggested by the abundant amount found in the central part of costal and bronchial cartilage. Here the quantity stored seems excessive for the local requirements of the cartilage itself. It is therefore tempting to speculate that these cartilages can serve as a subsidiary store of depot fat, which can be utilized if necessary to meet metabolic requirements elsewhere in the animal. It would thus be of interest to study the effect of starvation on the lipid content of costal and bronchial cartilage, and to compare the effect with that on subcutaneous adipose tissue. This has not been done during the present observations. All the animals used were healthy and on a normal laboratory diet, although 


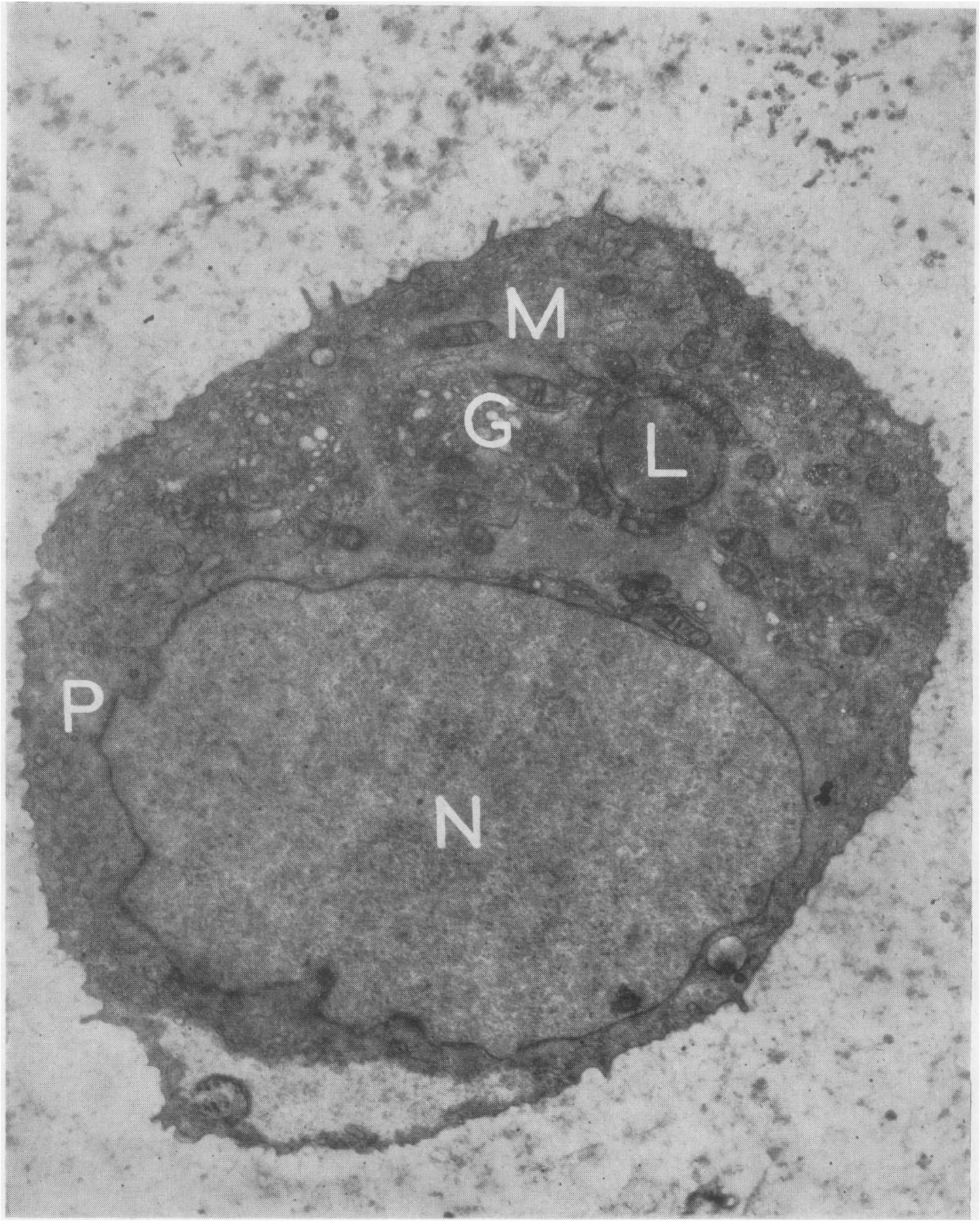

Fig. 9.-Electron micrograph of chondrocyte from femoral articular cartilage of adult rabbit. Note that lipid drop (L) is much smaller than nucleus (N). Mitochondria (M) are plentiful, and four of them partly surround the lipid drop (L). The cytoplasm also contains clear vesicles of Golgi type $(G)$, and numerous smaller vesicles of pinocytic type (P). Uranyl acetate. $\times 13,500$. 


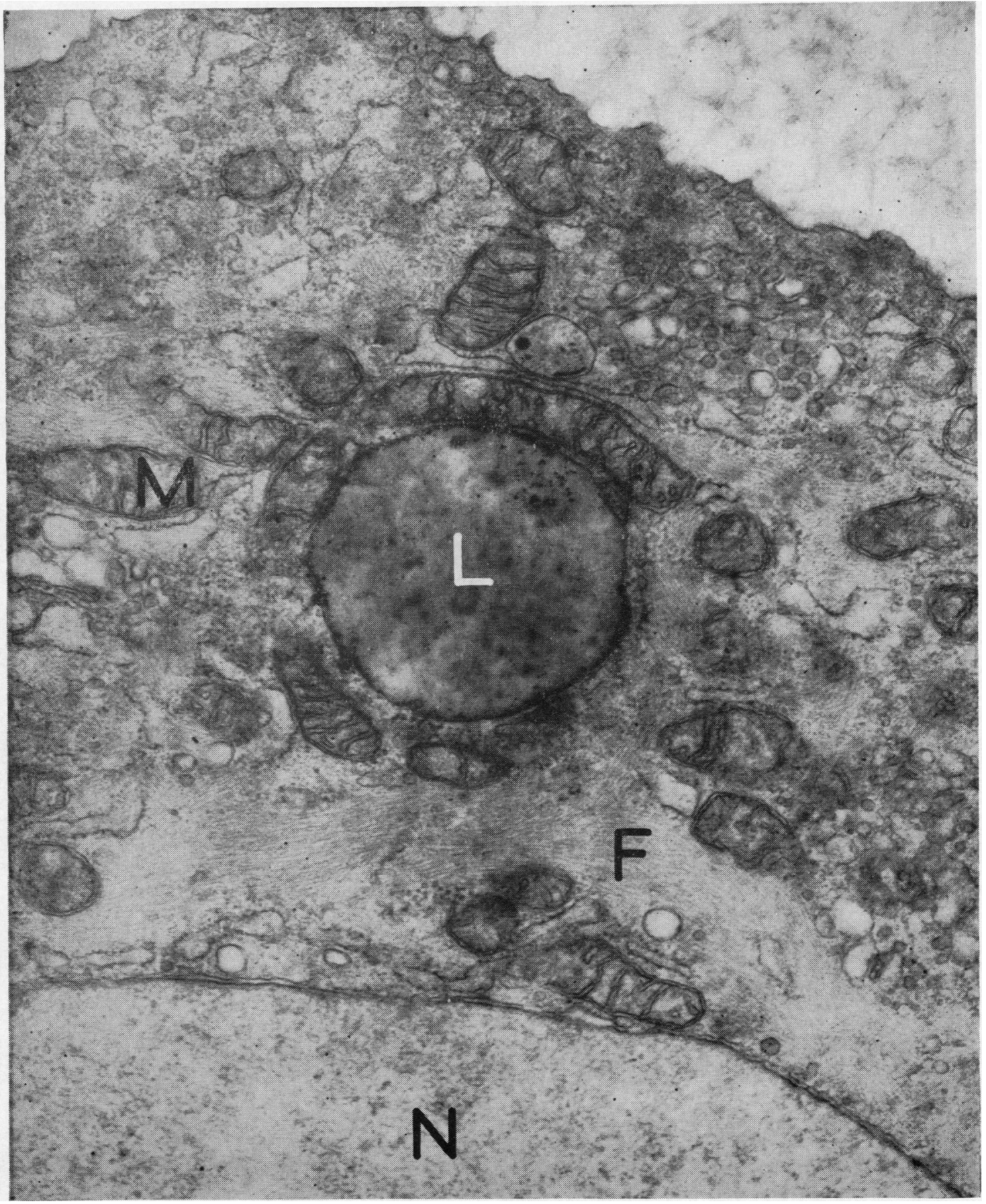

Fig. 10.-Higher magnification of lipid drop shown in Fig. 9. Lipid drop (L); part of nucleus (N); mitochondria (M); fine filamentous feltwork (F) in cytoplasm. Uranyl acetate. $\times 36,000$. 
Fig. 11.-Electron micrograph of cluster of three lipid drops (L) in chondrocyte of adult rabbit femoral articular cartilage. Note irregular rim of high electron density around each drop (R). Mitochondria (M) and fine filamentous feltwork (F) in adjacent cytoplasm. Uranyl acetate. $\times 48,000$

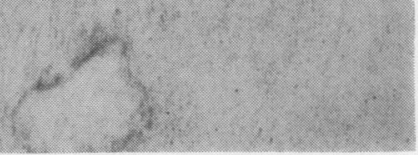




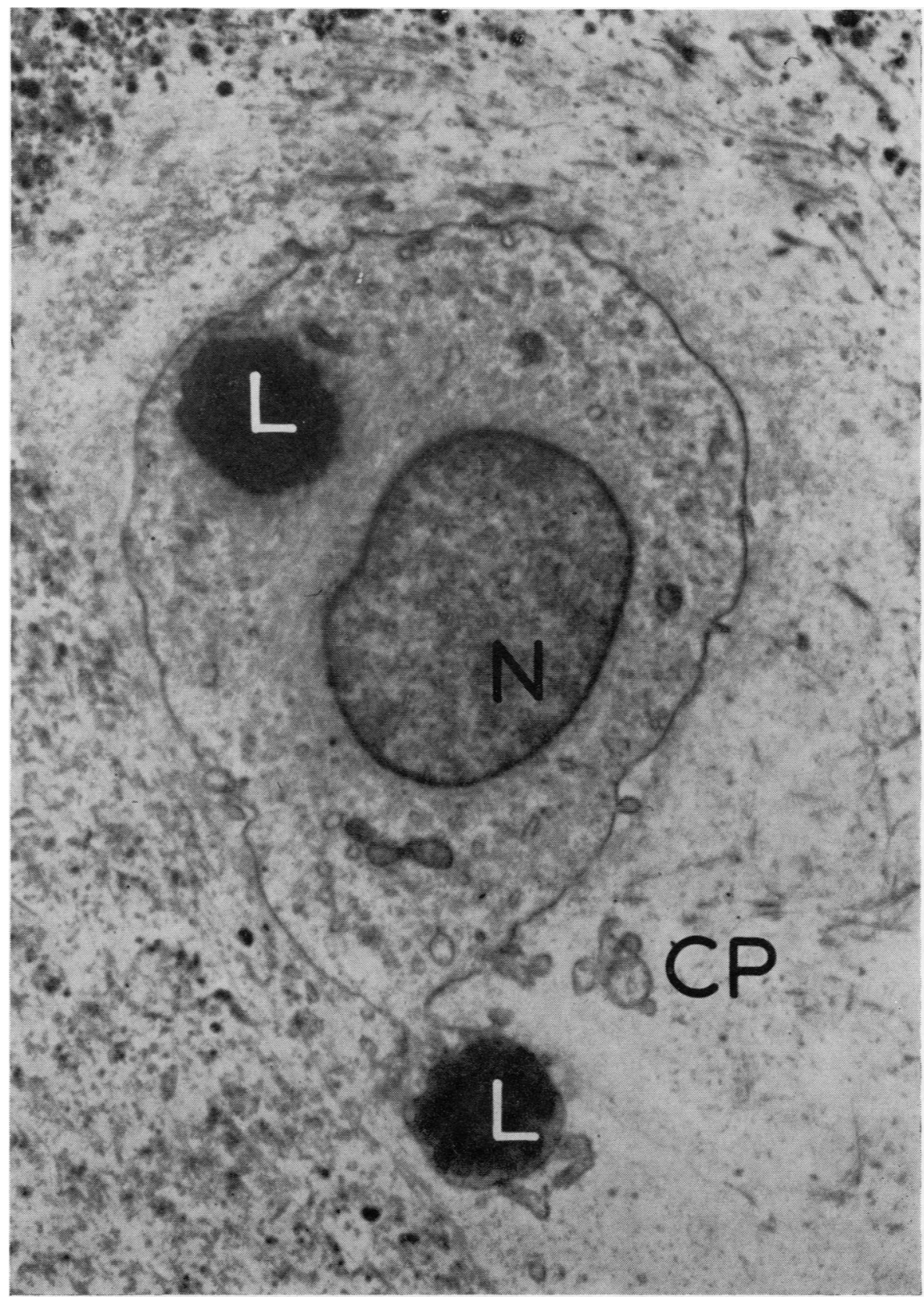

Fig. 12.-Adult human femoral articular cartilage (from a male aged 58 years). Electron micrograph showing chondrocyte containing lipid drops (L); nucleus (N); cytoplasmic processes (CP). Uranyl acetate. $\times 10,000$. 
the human material necessarily included tissue from persons in whom illness could have interfered with normal food intake.

Our observations indicate that the intra-cellular lipid pattern of hyaline cartilage is influenced by the age of the subject, the site of the cartilage, and the position of the chondrocyte in relation to the articular surface or perichondrium. Similar conclusions are apparent from a report by Stockwell (1963), who studied xiphisternal and articular cartilage of rabbits by use of frozen section techniques for the detection of total lipid, neutral fat, and phospholipid.

Species differences amongst the mammals we have examined seem to have a less important influence on the lipid pattern than age, the site of the sample, and the position of the chondrocyte in relation to the perichondrium or articular surface.

We have not concerned ourselves with the chemical identification of different lipids but with their general morphology and distribution. Oil red $\mathrm{O}$, which we used on frozen sections, certainly demonstrates neutral fats but is non-specific and probably also shows up many other lipids. Similarly, on electron microscopy no conclusion as to the chemical nature of a lipid drop can be drawn from the intensity of its reaction with osmium, since the variation in this from medium grey to black which we have noted may reflect mere technical variation in osmium fixation and staining rather than chemical differences in the fats.

\section{Summary and Conclusions}

The morphology and distribution of intra-cellular lipid has been studied in hyaline cartilage from the hamster, rabbit, rat, and man.

On light microscopy of oil red $\mathrm{O}$ stained frozen sections, lipid is seen in forms ranging from a single small or fine drop to many of these or to a large drop which can be much bigger than the nucleus. Electron microscopy shows a corresponding range of intra-cellular patterns, and indicates that each of these can occur in apparently healthy chondrocytes.

In the animals studied the influence of species on the intra-cellular lipid pattern is less striking than that of age, the site of the sample, and the position of the chondrocyte in relation to the articular surface or the perichondrium.

Often more intra-cellular lipid is demonstrable in a cartilage in adult life than in infancy and during the early growth period. Age differences have been noted between 2-day-old and 6-mth-old hamsters, between human babies and adults, and between $800 \mathrm{~g}$. and 2 to $3 \mathrm{~kg}$. rabbits.

In hyaline cartilage from adults the chondrocytes nearly all contain one or more lipid drops. In the central mass of adult costal and bronchial cartilage the cells can show drops larger than the nucleus, which they can displace to the periphery of the cell. By contrast, lipid drops of this size have not been encountered in subperichondrial or in articular chondrocytes.

This work was supported by a research grant from the Arthritis and Rheumatism Council. We are indebted to Dr. R. G. Lawler and Messrs. A. R. Bearn, O. Illman, and J. H. Webster for help in collecting samples of cartilage, and to Messrs. G. Colgrave and I. F. Coombe and others for technical assistance.

\section{REFERENCES}

Barnett, C. H., Cochrane, W., and Palfrey, A. J. (1963). Ann. rheum. Dis., 22, 389

-_, Davies, D. V., and MacConaill, M. A. (1961). "Synovial Joints", p. 14. Longmans, London.

Carlson, H. (1957). Acta orthop. scand., Suppl. 28.

Chase, W. H. (1959). J. Ultrastruct. Res., 2, 283.

Clark, E. R., and Clark, E. L. (1942). Amer. J. Anat., $70,167$.

Collins, D. H., and McElligott, T. F. (1960). Ann. rheum. Dis., 19, 318.

Davies, D. V., Barnett, C. H., Cochrane, W., and Palfrey, A. J. (1962). Ibid., 21, 11.

Fawcett, D. W. (1954). In "Histology", ed. R. O. Greep, chap. 8, p. 124. Churchill, London.

Glauert, A. M. (1961). In "Techniques for Electron Microscopy", ed. D. Kay, pp. 179-181. Blackwell, Oxford.

Ham, A. W., and Leeson, T. S. (1961). "Histology", 4th ed., p. $267 . \quad$ Pitman, London.

Montagna, W. (1949). Anat. Rec., 103, 77.

Palade, G. E. (1952). J. exp. Med., 95, 285.

Rhodin, J. A. G. (1963). "An Atlas of Ultrastructure." Saunders, Philadelphia.

Sheehan, J. F. (1948). J. Morph., 82, 151.

Silberberg, R., Silberberg, M., and Feir, D. (1964). Amer. J. Anat., 114, 17.

Stockwell, R. A. (1963). J. Anat. (Lond.), 97, 146.

Les lipides intra-cellulaires du cartilage

RÉSUMÉ

On a étudié la morphologie et la distribution du lipide intra-cellulaire dans le cartilage hyalin du hamster, du lapin, du rat et de l'homme.

Dans les coupes congélées et colorées par l'huile rouge $O$, observées sous le microscope lumineux, le lipide apparaît comme une seule goutte petite ou fine ou plusieurs gouttes similaires ou bien une grande goutte qui peut être plus volumineuse que le noyau. La microscopie électronique révèle une série correspondante de tableaux du lipide intra-cellulaire et montre que chacun de ceux-ci peut se voir dans des chondrocytes apparemment sains.

Chez les animaux étudiés l'influence de l'espèce sur l'image du lipide intra-cellulaire est moins frappante que celle de l'âge, de l'endroit du prélèvement et de la position 
du chondrocyte par rapport à la surface articulaire ou au périchondre.

Souvent on peut démontrer plus de lipide intracellulaire dans le cartilage de l'adulte que dans celui de l'enfant ou de l'individu à la période précoce de croissance. Des différences selon l'âge ont été notées entre des hamsters de 2 jours et de 6 mois, entre des nourrissons et des adultes humains, et entre des lapins de $800 \mathrm{~g}$. et de 2 à $3 \mathrm{~kg}$.

Dans le cartilage hyalin des adultes presque tous les chondrocytes contiennent une ou plusieurs gouttes de lipide. Dans la masse centrale du cartilage costal et bronchique, les cellules peuvent manifester des gouttes plus grandes que le noyau, qui peut se trouver déplacé vers la périphérie de la cellule. Par contre, des gouttes de lipide aussi grandes n'ont pas été rencontrées dans les chondrocytes souspérichondriaux ou articulaires.

\section{Los lípidos intracelulares del cartílago}

\section{SUMARIO}

Se estudiaron la morfología y la distribución del lípido intracelular en el cartílago hialino del hámster, del conejo, de la rata y del hombre.

En los cortes congelados, colorados con el aceite rojo
O y observados con el microscopio luminoso, el lípido se ve como una sola gota pequeña o fina, o unas cuantas gotas similares, o una gota voluminosa a veces mucho mayor que el núcleo. Microscopía electrónica muestra una serie correspondiente de imágenes del lípido intracelular e indica que cada una de ellas puede observarse en condrocitos aparentemente sanos.

En los animales estudiados la influencia de la especie sobre la imágen del lípido intracelular se destaca menos que la de la edad, del sitio de la biopsia y de la posición del condrocito respecto a la superficie articular o al pericondrio.

A menudo se puede evidenciar más de lípido intracelular en el cartílago del adulto que en él del niño o del individuo en el período temprano de crecimiento. Diferencias según la edad fueron notadas entre hámsters de 2 días y de 6 meses, entre infantes $y$ adultos humanos y entre conejos de $800 \mathrm{~g}$. y de 2 a $3 \mathrm{~kg}$.

En el cartílago hialino del adulto casi todos los condrocitos contienen una o más gotas de lípido. En la masa central del cartílago costal y bronquial las células pueden manifestar gotas mayores que el núcleo, el cual puede verse desalojado hacia la periferia de la célula. En cambio, gotas de lípido de este tamaño no fueron encontradas en los condrocitos subpericondriales o articulares. 